\title{
Religiosity and Intention towards Saving of a Muslim Minority in Greece
}

\author{
Nikolaos Satsios ${ }^{1}$, Spyros Hadjidakis ${ }^{2}$, Ioannis Sotiropoulos ${ }^{3} \&$ Nicholas Tsounis $^{4}$ \\ ${ }^{1}$ Department of Economics, International Hellenic University, Greece \\ ${ }^{2}$ Department of Finance and Economics, University of Nicosia, Cyprus \\ ${ }^{3}$ Department of Accounting and Finance, University of Ioannina, Greece \\ ${ }^{4}$ Department of Economics, University of Western Macedonia, Greece \\ Correspondence: Nikolaos Satsios, Department of Economics, International Hellenic University, Greece. E-mail: \\ nsatsios@teicm.gr
}

Received: March 14, 2020

Accepted: March 26, 2020

Online Published: March 31, 2020

doi: $10.5539 /$ ach.v12n1p28

URL: https://doi.org/10.5539/ach.v12n1p28

\begin{abstract}
Culture influences financial decisions of individuals therefore, by examining the cultural background of cultural differences stemming from difference in religious beliefs is of significance to better understand their preferences and financial decisions. This research examines the relation of religiosity and intention towards saving of Pomak households, a Muslim minority living in the northeaster part of Greece. Quantitative data, collected with field research using the Religious Commitment Inventory (RCI-10) and Warneryd's saving intention scale was used. The results reveal that there is a strong relation between religiosity and intention towards saving, indicating that the intention to save is affected by the religious norms of a person.
\end{abstract}

Keywords: Religiosity, Intention towards Saving, Muslim Minority

\section{Introduction}

In a constantly changing and increasingly globalised world, religions still play a significant role in influencing social and saving behaviour. However, although researchers have long recognised the importance of religious value systems in sociology (Anderson, 1970) and in psychology (Allport, 1967; Pargament \& Hahn, 1986), also, many authors such as (Arrunada, 2010; Belzen, 1999; Guiso et al., 2003; Karijin et al., 2007; McCleary, 2007; Mokhlis, 2009; Renneboog \& Spaenjers, 2012) have admitted and exhibited in full the importance of the religious sentiment in studies that examined their saving behaviour. The aim of the present investigation is to explore the effects of religion beliefs on the intention of a person towards saving in the Muslim minority of Pomaks in Greece. The Pomak population is living in the Greek part of the northeast region of Thrace, in three different prefectures: Xanthi, Rodopi and Evros. The sub goals of this research are to explore the religiosity of the sample according to their socio-demographic profile and to examine the differences between high and low religious individuals on the intention towards saving. The understanding of the saving behaviour of this minority living in this region is of a great interest for financial institutions and economic authorities. Minority populations are mainly placed in a disadvantageous situation when they apply for a loan, either from a bank or a similar economic establishment (Blanchard et al., 2008). Specifically, for Pomak minority, the socioeconomic segregation was the main reason why the moved their funds to other countries (mainly Turkey), at least until the early '90s when restrictive measures prevented them from investing them in the region (Anagnostou, 2003). Once these measures were abolished in 1991 the situation changed again (Anagnostou, 2003; 2001). The research also provides new insights into the relative emphasis of the various factors that influence saving behaviour in present days. The article is structured as follows. In section 2 there is a short recounting of the literature used for religiosity and intention towards saving, section 3 refers to the method and the statistical analysis which were used. In section 4 involved the outcomes and analysis of data, while section 5 presents the final conclusions.

\section{Literature Review}

Household saving behaviour has been studied in length. By saving it means the end result of a) making a decision and b) taking action that leads to the desired outcome; in this case, saving money, assets etc. (Lewis et al., 1995; Warneryd, 1999). As far as families are concerned, most follow the method of saving as it provides both a sense of 
security for any, predictable or not, future events and enhances their living standards (Anong \& DeVaney, 2010; Hira, 1987; Lee et al., 2000). Such decisions have a profound impact on how the household financially performs. There are essential reasons why economists and researchers are so deeply concerned with the way religious institutions function and how that affects the economy. Undoubtedly, one reason is the degree to which religion affects the formation of cultural conceptions in every society. This fact renders religion fascinating as a field of study, as it can and indeed does influence individuals as well as whole classes, groups or nations in terms of behaviour, sets of values, beliefs and ways of acting (Khraim, 2010). Religiosity is defined as "the extent to which an individual is committed to the religion he or she professes and its teachings, such as the individual's attitudes and behaviours reflect this commitment" (Johnson et al., 2001, p. 25). Being religious acquires different meaning for different persons (Slater et al., 2001) thus, making it more difficult for social scientists and marketing researchers to analyse. Religiosity is important as it is capable of influencing an individual cognitively and behaviourally. Religious persons have value systems that differ from those of the less religious and the non-religious (Hifza \& Hashanah, 2015). In accordance with Islam, one's convictions and submissiveness must be evident in the way they act. Therefore, Muslims should not just uphold their beliefs, but practise them, as well; otherwise, being forgetful or disobedient is considered a sin, a non-conformity to their religion (Souiden \& Rani, 2015). This set of principles that renders the divine in the centre of their existence, is supposed to act as a constant reminder and guide of how their whole life must adapt and evolve in order to fall in step with their religion (Souiden \& Rani, 2015).

As Muslims are guided by Islam in most aspects of their lives, its part in their handling of finances has been widely studied, as well. Delener (1994) concludes that there are four division of religiosity that people fit into: the highly religious, the moderate, the not so religious ones and not religious at all. Those levels appear to be related to their economic attitudes; those who are less religious don't seem to be influenced in one way or another when it comes to making financial decisions.

Religion commands that people stick to certain rules as far as their dress code, eating habits, ideas and spending are concerned (Souiden \& Rani, 2015). Mokhlis (2009) concludes that Muslim purchases are highly affected by their Islamic beliefs when it comes to shopping cars, food and clothes in Malaysia. Bonne et al. (2007) researched the purchase of halal meat in France and found out that the spending behaviour of Muslims is not similar to that of non-Muslims. Shaari \& Afirin (2010) reached the same conclusion and underlined the role of religion in individual lifestyles. Khraim (2010) also affirms this finding. Still, there should be a dividing line drawn between what Muslims believe and how they really behave; meaning, there are examples of Muslim people who, in spite of their religion, tend to indulge into a different lifestyle. According to previous studies (Arrunada, 2010; Belzen, 1999; Guiso et al., 2003; Karijin et al., 2007; McCleary, 2007; Mokhlis, 2009; Renneboog \& Spaenjers, 2012), intention towards saving have found to be significantly differentiated among the group of lower and higher religiosity. In contrast, other studies have shown that religiosity is not an important factor of intention (Dusuki \& Abdullah, 2007; Erol et al., 1990; Gerrard \& Cunningham, 1997; Haque et al., 2009). Understanding religiosity would allow to advance in this point, and to go deeper into uncovering the correlation between it and saving performance (Akerlof $\&$ Kranton, 2011), regarding the Pomak minority in Greece.

\section{Data \& Methodology}

A survey of Pomak households was conducted to collect data anonymously and on voluntary basis. A self-completion survey was given to 600 respondents in the region of Thrace in three different prefectures of Xanthi, Rodopi and Evros. The adult head of the household was questioned in order to retrieve information for the household. Households in the survey were selected through the snowball sampling procedure. From the total of the participants, 410 were male (68\%) and 190 were female (32\%). Most of the participants were living in the prefecture of Xanthi $(\mathrm{N}=386,64.3 \%)$, while $183(30.5 \%)$ were living in Rodopi and $31(5.2 \%)$ in Evros.

The Religious Commitment Inventory-10 (RCI-10) of Worthington et al. (2003) was used. The RCI-10 is a brief 10 -item screening assessment of the level of one's religious commitment using a 5-point Likert rating scale from 1 (not at all true of me) to 5 (totally true of me). Religious commitment refers to how much an individual is involved in his or her religion (Koenig et al., 2012). In particular, a religiously committed person is supposed to "adhere to his or her religious values, beliefs, and practices and use them in daily living" (Worthington et al., 2003, p.85). RCI-10 examines intrapersonal religious commitment (6 items) and interpersonal commitment (4 items) levels of the individual. An example of typical items in scale includes, "I enjoy working in the activities of my religious organization" and from the interpersonal subscale "I enjoy spending time with others of my religious affiliation".

For measuring the intention towards saving the Warneryd's saving intention scale was used, which consists of twenty-one attitude questions describing the individual's intention to saving (Warneryd, 1996a; 1996b). He 
introduced five subscales named "thrift", "saving involvement", "saving habits", "shame of debt", and "no need to save". According to Warneryd (1999, p.73) thrift is "a summary concept for all sorts of psychological factors that were assumed to affect savings". The saving involvement subscale depicts how each person conceives and renders significance and concern on any given item in his environment (Zaichkowsky, 1986). The saving habits subscale reflects the social comparison effect that essentially influences the saving behaviour (Duesenberry, 1949; Fisher, 1930; Keynes, 1936). Shame of debt subscale demonstrates the unanticipated events that certainly contribute to debt perceptions of the individuals' future needs and prompt their actions (Warneryd, 1999). Finally, no need to save subscale represents the individual's perception that living on less will pay off in the future (Kouzes \& Posner, 2011). Those who are more aware of ways to save tend to act differently as compared to those who aren't (Bernheim \& Garrett, 2003; Lusardi, 2008).

Pearson correlation coefficients were computed to quantify the linear correlation of the scales of religiosity and intention towards saving. The descriptive $\mathrm{K}$ - cluster method was applied to split the sample in two homogeneous groups regarding to the religiosity and intention towards saving scores. Student $\mathrm{t}$ - test for two independent samples was conducted to evaluate the statistical significance of the difference among the two clusters that were defined after the $\mathrm{K}$ - clusters method. As the sample was a sample of convenience, it was not reliable to use a statistical method such as multinomial probit, which statistically generates conclusions from the sample for the population. Instead, the K- cluster descriptive method was chosen which is simple in both the application and the presentation of the findings.

\section{Results}

Religiosity was found to be positively correlated to intention towards saving (Table 1). In particular, all intention subscales was significantly positively correlated with religiosity, with the subscale of thrift having the larger correlation $(\mathrm{r}(600)=0.451, \mathrm{p}<.01)$ while on the other hand shame of debt had the smaller coefficient $(\mathrm{r}(600)=$ $0.087, \mathrm{p}<.05)$.

Table 1. Correlation among religiosity and intention towards saving

\begin{tabular}{ccccc}
\hline Thrift & Saving Involvement & Saving Habits & Shame on Debt & No Need to Save \\
\hline $0.451^{* *}$ & $0.377^{* *}$ & $0.102^{*}$ & $0.087^{*}$ & $0.284^{* *}$ \\
\hline
\end{tabular}

** Correlation is significant at the 0.01 level (2-tailed).

*Correlation is significant at the 0.05 level (2-tailed).

Source: Authors' calculations

The above results suggest that there are specific differences in the religiosity of the sample according to their socio-demographic profile. In order to enlighten and clarify the differences between high and low religious people, the $\mathrm{K}$ - cluster method was applied to separate the sample into 2 groups according to their religiosity and their intention toward saving subscales (Table 2$)$. The first group $(\mathrm{N}=292)$ was the group of lower religiosity $(\mathrm{M}=23.5$, $\mathrm{SD}=5.7)$ while the second $(\mathrm{N}=308)$ was the group of larger religiosity $(\mathrm{M}=36.9, \mathrm{SD}=4.7)$. The lower religiosity group was the younger part of the sample $\left(\mathrm{M}_{1}=28.7, \mathrm{SD}_{1}=10.6 \mathrm{vs} \mathrm{M}_{2}=36.9, \mathrm{SD}_{2}=4.7\right)$, being single or married without children (Group1: 69\% vs Group2: 55\%) and more educated that the second group (percent of high school graduation Group1: $77 \%$ vs Group2: $62 \%$ ). The religiosity scores of the Group1 was comparable to previously reported findings of group of general population in various religious or minority groups (Table 4, row 1, $2,3,15$ ) whereas the Group 2 was comparable to persons having a strong religious background (Table 4, row 4, 5 , $12,14)$.

Table 2. Intention towards saving differences among lower and higher religious group

\begin{tabular}{llcc}
\hline & Group 1 & Group 2 & P \\
\hline Thrift & $3.3(0.7)$ & $3.8(0.6)$ & $<0.001$ \\
Saving Involvement & $3.1(0.8)$ & $3.6(0.7)$ & $<0.001$ \\
Saving Habits & $3.4(0.5)$ & $3.5(0.6)$ & 0.053 \\
Shame on Debt & $2.9(0.7)$ & $3.1(0.8)$ & 0.016 \\
No need to save & $3.1(0.8)$ & $3.5(0.8)$ & $<0.001$ \\
\hline
\end{tabular}

Source: Authors' calculations 
Table 3. Correlation among religiosity and intention for each group

\begin{tabular}{cccccc}
\hline Group & Thrift & Saving Involvement & Saving Habits & Shame on Debt & No Need to Save \\
\hline $\mathbf{1}$ & $0.224^{* *}$ & $0.168^{* *}$ & 0.031 & -0.073 & $0.141^{*}$ \\
$\mathbf{2}$ & $0.427^{* *}$ & $0.357^{* *}$ & 0.104 & $0.113^{*}$ & $0.244^{* *}$ \\
\hline
\end{tabular}

Source: Authors' calculations

Thus, the above findings suggest that the level of the religiosity of a person is strongly related to other important decisions that this person is taking in his/her life. It is worth noting that the effect of religiosity on intention at the high religiosity group was significantly larger of the corresponding effect on the first group (Table 3), indicating that the intention to save for the younger and better educated Pomaks is not highly affected by the Muslim cultural tradition.

Specifically, Table 4 summarises the means and standard deviations for groups totalling almost 2000 people. For secular groups, means for the full-scale RCI are between 21 and 26 (SDs between 10 and 12). According to theorizing and reviews of research (Worthington et al., 1996; Worthington, 1988), people scoring greater than one $\mathrm{SD}$ higher than the mean should be considered highly religious. There is evidence that they view the world more in terms of their religious worldview than do less religious people or nonreligious people. Therefore, religion is expected to play a part in counselling and certainly in the perception of clients. Thus, according to theory (Worthington, 1988), a full-scale RCI-10 score of 38 or higher would justify considering a person to be highly religious.

Table 4. Normative Data for groups totalling about 2000 people

\begin{tabular}{lll}
\hline & Sample & Total RCI-10 \\
\hline 1 & University students & $23.1(10.2)$ \\
2 & University students & $23.6(10.8)$ \\
3 & University students & $25.7(11.9)$ \\
4 & Christian students at explicitly Christian Colleges & $38.5(7.9)$ \\
5 & Married, Christian adults & $39.0(9.3)$ \\
6 & University students & $22.8(10.5)$ \\
7 & Sub-sample Buddhist students & $21.1(8.8)$ \\
8 & Sub-sample Christian students & $25.8(10.3)$ \\
9 & Sub-sample Hindu students & $24.5(9.9)$ \\
10 & Sub-sample Muslim students & $29.7(15.1)$ \\
11 & Sub-sample Non-religious students & $14.9(7.1)$ \\
12 & Clients in Christian Agencies & $37.0(10.4)$ \\
13 & Clients in a secular counselling center & $21.4(11.7)$ \\
14 & Therapists in Christian agencies & $45.9(4.4)$ \\
15 & Therapists in a secular counselling center & $25.5(11.3)$ \\
\hline
\end{tabular}

Source: Worthington et al. $(1996 ; 1988)$

\section{Conclusions}

This research offers substantial theoretical value, which helps better comprehend the importance of religiosity that is significant as a cultural-based predictor of the Muslim's saving behaviour and it could prove to be a valuable resource to the financial institutions in order to discover new opportunities for considering this minority group as part of their customers. According to the results of the research the effect of religiosity on intention at the high religiosity group was significantly larger than the corresponding effect on the lower religiosity group, indicating that the intention to save for the younger and better educated Pomaks is not highly affected by the Muslim cultural tradition. Young Pomaks savers consist an intriguing mass of people for marketing researchers, as these attempts to form their identity and attitude on the basis of how they save and spend money. This pattern of behaviour defines who they are (Holbrook \& Schindler, 1989). They can be strong influencing forces for their surroundings, in terms of marketing interest, and forge other behaviour on financial issues (Grant \& Waite, 2003). Young-adult consumers act as agents of change within their social and cultural circles (Leslie et al., 2001). Therefore, young Pomaks are depicted as an intriguing group with regard to international marketing. 
In an international setting, concerning financial institutions, the present research can be viewed as an effort towards the identification of religiosity as a factor influencing individual's saving behaviour. Previous studies have thoroughly documented the importance of religious factors affecting bank customers' attitudes and saving preferences (Baele et al., 2014; Dahari et al., 2015; Metwally, 1996; Newaz et al., 2016; Souiden \& Rani, 2015). Thus, there seems to be also an acquisition of useful information for both economists and sociologists on the saving behaviour of the Pomaks. Therefore, the financial institutions can develop financial products or services according to their needs and preferences so as to match or exceed their expectations and allow managers to reconsider alternative methods when it comes to saving behaviours and adapt their marketing strategies in accordance (Souiden \& Rani, 2015), while knowledge and understanding of the Pomaks' characteristics can assist in social interventions aiming to provide guidance in the pursuit of a healthy household's financial life (Satsios \& Hadjidakis, 2018). The study scope was limited to the Pomaks in the Greek side of Thrace, but there are Pomak populations in the Bulgaria side as well. Consequently, future research could include comparative studies involving Pomaks on other countries (such as Bulgaria).

\section{Conflict of interests}

The authors declare that there is no conflict of interests regarding the publication of this paper.

\section{References}

Akerlof, G., \& Kranton, R. (2011). Identity economics: How our identities shape our work, wages, and well-being, Princeton. NJ: Princeton University Press. https://doi.org/10.1515/9781400834181

Allport, G. W. (1967). The Individual and His Religion: A Psychological Interpretation. Macmillan, New York, NY.

Anagnostou, D. (2001). Breaking the cycle of nationalism: The EU, regional policy and the minority of Western Thrace, Greece. South European Society and Politics, 6(1), 99-124. https://doi.org/10.1080/714004933

Anagnostou, D. (2003). Minorities and the Nation-State in 20th century Greece. Journal of Southern Europe and the Balkans, 5(3), 381-386. https://doi.org/10.1080/1461319032000171830

Anderson, C. (1970). White Protestant Americans: From National Origins to Religious Group. Prentice-Hall, Englewood Cliffs, NJ.

Anong, S. T., \& DeVaney, S. A. (2010). Determinants of adequate emergency funds including the effects of seeking professional advice and industry affiliation. Family and Consumer Sciences Research Journal, 38(4), 405-419. https://doi.org/10.1111/j.1552-3934.2010.00035.x

Arrunada, B. (2010). Protestants and Catholics: Similar work ethic, different social ethic. Economic Journal, 120, 890-918. https://doi.org/10.1111/j.1468-0297.2009.02325.x

Baele, L., Farooq, M., \& Ongena, S. (2014). Of religion and redemption: Evidence from default on Islamic loans. Journal of Banking \& Finance, 44(6), 141-159. https://doi.org/10.1016/j.jbankfin.2014.03.005

Belzen, J. A. (1999). The cultural psychological approach to religion: Contemporary debates on the object of the discipline. Theory \& Psychology, 9(2), 229-255. https://doi.org/10.1177/095935439992004

Bernheim, D., \& Garrett, D. (2003). The effects of financial education in the workplace: Evidence from a survey of $\begin{array}{lllll}\text { households. Journals of Public } & \text { Economics, } & \text { 87(7), } & \text { 1487-1519. }\end{array}$ https://doi.org/10.1016/S0047-2727(01)00184-0

Blanchard, L., Zhao, B., \& Yinger, J. (2008). Do lenders discriminate against minority and woman entrepreneurs? Journal of Urban Economics, 63(2), 467-497. https://doi.org/10.1016/j.jue.2007.03.001

Bonne, K., Vermeir, I., Bergeaud-Blackler, F., \& Verbeke, W. (2007). Determinants of halal meat consumption in France. British Food Journal, 109(5), 367-386. https://doi.org/10.1108/0070700710746786

Dahari, Z., Abduh, M., \& Fam, K. S. (2015). Measuring service quality in Islamic banking: Importance-performance analysis approach. Asian Journal of Business Research, 5(1), 15-28. https://doi.org/10.14707/ajbr.150008

Delener, N. (1994). Religious contrasts in consumer decision behaviour patterns: Their dimensions and marketing implications. European Journal of Marketing, 28, 36-53. https://doi.org/10.1108/03090569410062023

Duesenberry, J. S. (1949). Income, saving and the theory of consumer behaviour. Cambridge, MA: Harvard University Press. 
Dusuki, A. W., \& Abdullah, N. I. (2007). Why do Malaysian customers patronise Islamic banks? International Journal of Bank Marketing, 25(3), 142-160. https://doi.org/10.1108/02652320710739850

Erol, C., Kaynak, E., \& Radi, E. B. (1990). Conventional and Islamic banks: Patronage behaviour of Jordanian customers. International Journal of Bank Marketing, 8(4), 25-35. https://doi.org/10.1108/02652329010004231

Fisher, I. (1930). The theory of interest as determined by impatience to spend income and opportunity to invest it. New York: The Macmillan Company.

Gerrard, P., \& Cunningham, J. B. (1997). Islamic banking: A study in Singapore. International Journal of Bank Marketing, 15(6), 204-216. https://doi.org/10.1108/02652329710184433

Grant, I. C., \& Waite, K. (2003). Following the yellow brick road-young adults' experiences of the information super-highway. Qualitative Market Research: An International Journal, 6(1), 48-57. https://doi.org/10.1108/13522750310457375

Guiso, L., Sapienza, P., \& Zingales, L. (2003). People's opium? Religion and economic attitudes. Journal of Monetary Economics, 50(1), 225-282. https://doi.org/10.1016/S0304-3932(02)00202-7

Haque, A., Osman, J., \& Ismail, A. Z. (2009). Factor influences selection of Islamic banking: A study on Malaysian customer preferences. American Journal of Applied Sciences, 6(5), 922-928. https://doi.org/10.3844/ajassp.2009.922.928

Hifza, I., \& Hashanah, I. (2015). A Generational Cohort Study of the Relationship between Religious Intensity and Religious Assurance for the Purchase of Non-food Products. International Journal of Economics and Financial Issues, 5, 330-334.

Hira, T. (1987). Households' financial management factors influencing solvency and satisfaction. The Journal of Japan Society of Household Economics, 10, 199-210.

Holbrook, M., \& Schindler, R. M. (1989). Some explanatory findings on the development of musical tastes. Journal of Consumer Research, 16(1), 119-124. https://doi.org/10.1086/209200

Johnson, B. R., Jang, S. J., Larson, D. B., \& Li, S. De. (2001). Does Adolescent Religious Commitment Matter? A Reexamination of the Effects of Religiosity on Delinquency. Journal of Research in Crime Nd Delinquency, 38(1), 22-44. https://doi.org/10.1177/0022427801038001002

Karijin, B., Iris, V., Florence, B. B., \& Wim, V. (2007). Determinants of halal meat consumption in France. British Food Journal, 109(5), 367-386. https://doi.org/10.1108/0070700710746786

Keynes, J. M. (1936). The general theory of employment interest and money (pp. 1-472). London: Macmillan Press Ltd. ISBN-10: 1535221984.

Khraim, H. (2010). Measuring religiosity in consumer research from an Islamic perspective. Journal of Economics Administrative Sciences, 26(1), 52-78. https://doi.org/10.1108/10264116201000003

Koenig, H. G., King, D., \& Carson, V. B. (2012). Handbook of religion and health (2nd ed.). Publisher: Oxford University Press.

Kouzes, J., \& Posner, B. (2011). Credibility: How leaders gain and lose it, why people demand. Publisher: Jossey-Bass. https://doi.org/10.1002/9781118983867

Lee, S.-L., Park, M.-H., \& Montalto, C. P. (2000). The effect of family Life Cycle and financial management practices on household saving patterns. International Journal of Human Ecology, 1(1), 79-93.

Leslie, E., Sparling, P. B., \& Owen, N. (2001). University campus settings and the promotion of physical activity in young adults: Lessons from research in Australia and the USA. Health and Education, 101(3), 116-125. https://doi.org/10.1108/09654280110387880

Lewis, A., Webley, P., \& Furnham, A. (1995). The new economic mind. The social psychology of economic behaviour (2nd ed.). Hemel Hempstead: Harvester Wheat sheaf.

Lusardi, A. (2008). Household saving behaviour: The role of financial literacy, information, and financial education programs (pp. 1-43). NBER Working Paper No. 13824. https://doi.org/10.3386/w13824

McCleary, R. (2007). Salvation, damnation and economic incentives. Journal of Contemporary Religion, 22(1), 49-74. https://doi.org/10.1080/13537900601114503 
Metwally, M. (1996). Attitudes of Muslims towards Islamic banks in a dual-banking system. American Journal of Islamic Finance, 6(1), 11-17.

Mokhlis, S. (2009). Relevancy and measurement of religiosity in consumer behavior research. International Business Research, 2(3), 75-84. https://doi.org/10.5539/ibr.v2n3p75

Newaz, F. T., Fam, K. S., \& Sharma, R. R. (2016). Muslim religiosity and purchase intention of different categories of Islamic financial products. Journal of Financial Services Marketing, 21(2), 141-152. https://doi.org/10.1057/fsm.2016.7

Pargament, K. I., \& Hahn, J. (1986). God and the just world: Causal and coping attributions to god in health situations. Journal for the Scientific Study of Religion, 25(2), 193-207. https://doi.org/10.2307/1385476

Renneboog, L., \& Spaenjers, C. (2012). Religion, economic attitudes and household finance. Oxford Economic Papers, 64(1), 103-124. https://doi.org/10.1093/oep/gpr025

Satsios, N., \& Hadjidakis, S. (2018). Applying the Theory of Planned behaviour (TPB) in saving behaviour of Pomak Households. International Journal of Financial Research, 9(2), 122-133. https://doi.org/10.5430/ijfr.v9n2p122

Shaari, J. A. N., \& Afirin, N. S. M. (2010). Dimension of halal purchase intention: A preliminary study. International Review of Business Research Papers, 6(4), 444-456.

Slater, W. E., Hall, T. W., \& Edwards, K. J. (2001). Measuring religion and spirituality: Where we are and where are we going? Journal of Psychology and Theology, 29(1), 4-21. https://doi.org/10.1177/009164710102900102

Souiden, N., \& Rani, M. (2015). Consumer attitudes and purchase intentions toward Islamic banks: The influence of religiosity. International Journal of Bank Marketing, 33(2), 143-161. https://doi.org/10.1108/IJBM-10-2013-0115

Warneryd, K. E. (1996a). Personality and saving, VSB-Centre savings project progress report. No. 39, Tilburg, The Netherlands: Tilburg University, Centre for Economic Research.

Warneryd, K. E. (1996b). Saving attitudes and saving behaviour. In C. Roland-Levy (Eds.), Proceedings of the 21th IAREP Colloquium: Social and Economic Representations (pp. 798-811). Paris: Universite Rene Descartes, Institute de Psychology.

Warneryd, K. E. (1999). The psychology of saving. A study of economic psychology. Cheltenham: Edward Elgar Publishing.

Worthington, E. L. Jr. (1988). Understanding the values of religious clients: A model and its application to counselling. Journal of Counseling Psychology, 35(2), 166-174. https://doi.org/10.1037/0022-0167.35.2.166

Worthington, E. L. Jr., Kurusu, T. A., McCullough, M. E., \& Sandage, S. J. (1996). Empirical research on religion in counseling: A 10-year review and research prospectus. Psychological Bulletin, 119, 448-487. https://doi.org/10.1037/0033-2909.119.3.448

Worthington, E. L. Jr., Wade, N. G., Hight, T. L., McCullough, M. E., Berry, J. T., Ripley, J. S., Berry, J. W., Schmitt, M. M., \& Bursley, K. H. (2003). The Religious commitment Inventory-10: Development, refinement and validation of a brief Scale for research and counseling. Journal of Counseling Psychology, 50(1), 84-96. https://doi.org/10.1037/0022-0167.50.1.84

Zaichkowsky, J. L. (1985). Measuring the involvement construct. Journal of Consumer Research, 12, 189187186. https://doi.org/10.1086/208520

\section{Copyrights}

Copyright for this article is retained by the author(s), with first publication rights granted to the journal.

This is an open-access article distributed under the terms and conditions of the Creative Commons Attribution license (http://creativecommons.org/licenses/by/4.0/). 